\title{
Building the Modern Albanian State on Oriental Mentality
}

\section{Hazbi Lika}

Lecturer at Aleksander Moisiu University of Durres

\begin{abstract}
This paper aims at proving that the discourse that promotes our national identity is grounded on the new political context which initiated after the Declaration of Independence and the formation of the first Albanian state. During such a discourse, in the given period, prevails the debate on: the west openly rejects the orient. The elite that was active in politics seems to be more restrained, while the intellectual one, especially those educated in the AustroGermanic region, declare open war on the Orient. The Political Assembly of Prizren and Vlora bring evidence of an ethnic identity which is changeable with respect to the new environment created. Albanian elites, especially the intellectual ones in the light of orientalist, rightly denounce the orient and oriental culture by not appreciating the historical environment in which our ethnic identity had to be maintained for a period of five centuries. The discourse of this period shows that our national identity began to become quite different adapting to the new reality that was created.
\end{abstract}

Keywords: modern Albanian state, oriental mentality

\section{Introduction}

Before and after the Declaration of Independence, the circumstances and the new political environment that was created, conditioned the way our national identity was built. If during the period of the National Renaissance, the elite of scholars and poets repeatedly rejected the Turkish, Ottoman and Oriental culture, during the period of Independence and at the time of the establishment of the Albanian state by an elite majority, the Oriental was hated and opposed in terms of culture and civilization. During the Renaissance, Europe and Europeanization were just political realities and a geographical notion. They were not mentioned as political and cultural models to be referred to. In factit was not even recognized by them as a cultural union as civilization, where our identity was required to be identified with it as emphasized later in the political and intellectual discourse of the 20 s and 30s. Certain events give us enough information that despite the efforts of the educated elite to present Albania with early roots in European civilization, these events prove that our people in many of their behaviors showed close connection to Oriental Cultural. 
The challenge that Esat Toptani announced to his political rival Ismail Vlora proves that he knew well the sensibilities and Ottoman mentality of the people and used them to increase his popularity which in fact became a real threat to political rivals. Next occurrence: HaxhiQamil

Movement, which regardless of the various viewpoints and interpretations, united around itself a part of the elite of Muslim believers, Hajjis and Imams, who had been educated in theology, rejecting the westernization of Albania. This political figure increased his protagonism by recognizing the sensibility of the people and manipulating them. Even Ahmet Zogu built institutions with European grounds, although he had almost oriental political principles, so it was easier for him to have the rule of power. This article provides an overview of the political and cultural debates of this period, where although each stands out with its own individuality, what they have in common is that the changes of the conditions of the time and the political context the debate generally takes a different geo-cultural orientation. In this overview our national identity begins to be reconstructed.

\section{The beginnings of the Albanian state}

The most important public act that proves the beginning of a new Albanian state, begins in the early twentieth century with the declaration of independence on 1912. A former senior official of the imperial administration and MP raises the flag in Vlora, declaring Albania to be independent of the SublimePorte. This political act proves that the fate of Albania would be debated less in Turkish parliaments than in the chancelleries of Europe. IsmalKemal Bey inVlora, diplomat and high official of the Ottoman Empire, loyal and worthy to serve the Sultan until the end of his life, when the Sultan weakened his power in the Turkish Balkans, he was introduced as the head of the Assembly of Vlora, as the father of the nation. We emphasizes that the memoirs of Ismail Qemali sent to the Sultan; "My sense of loyalty was so strong and the determination of my thoughts was so real that these would not weaken it from the vile impulses of some clowns who disturbed the mind of your majesty. Your Majesty would acknowledge today that my insistence on presenting the truth to you, perseverance that had crossed the boundaries of education, and from the faithful man, to provide the means of salvation for your people and empire. Do not think that by appearing in some modest events, I intend to oppose your imperial image. The memorandum of Ismail Qemali to the sultan to prevent the movement of peoples against the empire to protect the greatness of the empire and guarantee its eternity, as well as to prevent the open interference of the Great Powers in the internal affairs of the empire. Ismail Qemali, swore allegiance and devotion to the empire of the Sultan and only 15 years later he would put on the cloakof the father of the nation. Of course, this proves that this career clerk until the end of the XIX century was not yet affected by the Renaissance Romanticism.

At least until the eve of the declaration of independence from the numerous correspondences he had with the Sultan, Ismail Qemaliit is proven that theOttoman 
was a system and legitimate social order and Islam as a doctrinal product of the Ottoman was the religion with which Albanians identified themselves. Even the discourse of the Declaration of Independence on what we know today is not in line with the nationalist rhetoric. It is very short and telegraphic. "In Vlora on 15/28 of the third Autumn on 28/1912. "After the words said by Ismail QemalBey, showing the great danger in which Albania is, all

the delegates with unanimitydecided that Albania today should be free and independent." Find below the text written in ottoman.

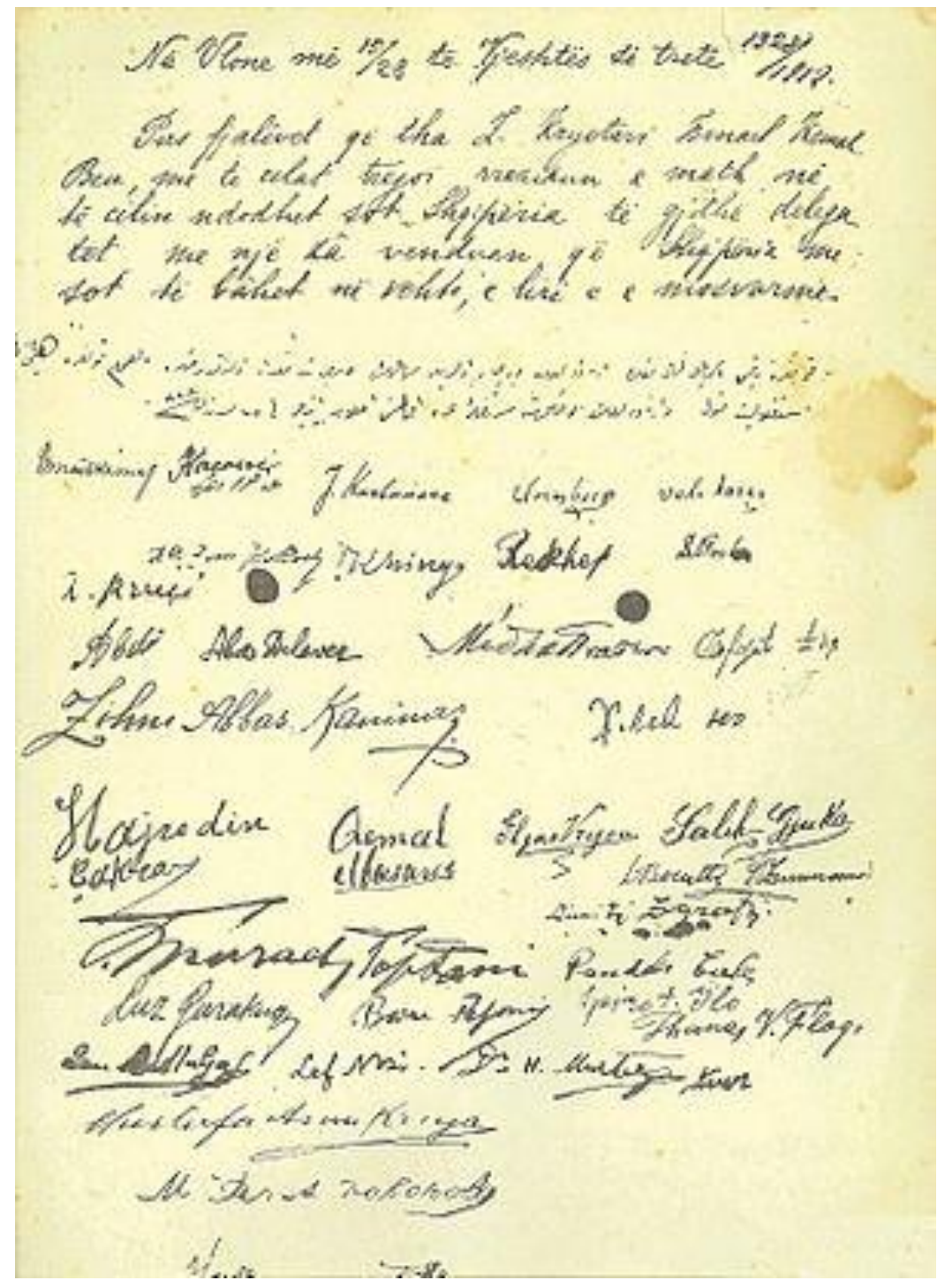


The statement, as an admirable diplomatic sense,has no sensitive national sentiment. The content and national purpose of the declaration was diplomatically clarified. But the content of the Declaration of Independence does not express rejection of Ottoman as a cultural notion, nor of the Ottoman Empire, as a political system, but it sees a danger for Albania and due to this danger , Albania needed to gain independence. And this danger, according to Ismail Qemali and many signatories of this statement, was not the Ottoman Empire, but the weakening of this empire in the Balkans. This statement of Ismail Qemal of Vlora and his contemporaries, was not just a public statement, but also became the main problem of securing the territory during his rule. Many correspondences of the time show how Ismail Qemali addressed his mayors, especially Aqif Pasha of Elbasan, to keep good relations and cooperate with the Turkish garrisons to protect the border security from Serbian, Greek, and Montenegrin attacks. From these correspondence of Ismail with the Sultan and with the commanders of the Turkish garrisons, Turkey was no longer a danger for Albania, but the new geopolitics that was created in the Balkans. Ismail Qemali comes along with the renaissance, and in all his political behavior, as in the time he served the Sultan, (while the renaissance had built their nationalist-romantic discourse) and as the founder of the Albanian state, during the speechin public, did not approve of the

renaissance nationalist romanticism. The Renaissance and Ismaili were two different testimonies of almost the same period. They claim to the western perspective of the Albanians, while the other claim to the Albanian oriental reality. The poet wants to do things right, while the politician is forced to say things the way they really are. From what we have said, a questing raises: was Albania in the majority of its populationculturally Ottoman, or had it internally rejected the Ottoman? Most of the textbooks we have studied tell us that Albanians, as a European nation, hated Ottoman throughout the centuries, and that Orientalism had entered like a foreign flesh. But how true itis this we will know in the following passage of this article.

\section{Political rivalry as evidence of a reality}

In the Albanian reality of the time, where politics debates and conflicts in its daily life, exactly where two important political rivals are between each-other; Ismail Qemali and Esat Pasha. For a time they co-ruled and later irreconcilable political opponents. The first refined and more aristocratic, while the second, popular, and more adventurous. As a minister and then as a former minister of Ismail Qemali, he

seriously threatened the government of Vlora. To approach the question of who was really the Ottoman sensibility of the people in this period, we quote from the telegram of January 13, 1914 of Aqif Pasha as prefect of Elbasan supporting Ismail Qemali where he informs the government of Vlora about the activity of the rebels of Esat Toptan. "The rebels, under the command of an officer named Hamid, sent by Esad Pasha, occupied 15 villages. These, after arming them, take them with them and thus are increasing their power. They draw the people with them by asking them who the Ottomans are and who the Latins are, arming them under the guise of Muslimism and 
Ottoman . Since most of the people are fanatical and have not lost their feelings for the Ottomans, they sympathetically welcomed their propaganda and joined them. In the same telegram text, Aqif Elbasani notifies the government of Vlora; "Now that we are writing this telegram, we receive reliable information that a special army of Tirana, under the command of the adopted son of the mufti of Tirana and the brother of the mufti of Dibra have started to attack and this army is reaching 7000-8000 people will attack us and surround Elbasan on all sides.

Again a telegram from AqifElbasani dated 12 January 1914, sent to the government of Vlora informed that the people of Esat Pasha Toptan were inciting the peasantry against the government; "Considering the false fame of Esat Pasha, in his name, Dervish Bey, in every village he himselfshows the villagers the picture of Prince Wied that was published in the Albanian newspaper in Vlora and tells them: "The government of Elbasan and the Tosks, come and see, this orthodoxwants to become our king", shedding tears he would say: "Islam is over" and with these tears heignited and provoked the feelings of the ignorant peasants. According to the testimonies of his opponents, (Ismail Qemali and AqifElbasani), Esat Pasha, he inspired the population of Central Albania by demanding a Turkish prince appointed by the Sultan and Albania a Turkish principality, seeking Turkish and Arabic and Sheh Islam and opposed Prince Wied appointed by the International Control Commission. Given the fact that the government of Vlora was legitimized by this commission consisting of the great powers of the time: England, Austria, France and Italy did not extend their authority within the boundaries set by this commission, because of EsatToptanit.

The evidence of his opponents does not hold accusations about the funding sources ofEsat, but the main accusation against him is that he abuses the feelings of the rural population in the name of theOttoman. This popularity of Esat rises due tosuch sentiments and which certainly an experienced politician like EsatToptani uses for his own accounts. Often in the accusations of the opponents, it is considered that the popularity of EsadToptan enhanced because he knew how to use the Ottoman sensibility that exists in the rural population. These telegrams prove that in the rural population, of course, in the Muslim part the majority had an inspiring feeling for the Ottoman which would push them towards action for military mobilization.

Another event that proves this popular feeling, especially in the crowded peasants, is the uprising of HaxhiQamil known as the Islamic revolt, or the Muslim Uprising in Albania. The most proclaimed slogan in this uprising was: "We love our Father." Under these calls, an uprising took place which later expanded. The First World War comes and the uprising is suppressed, which changes the course of developments in Albania of that period, sentencing HaxhiQamil to death as a leader with his close associates.

In the context of this evidence, another thing that shows the religious spirit of the people in the Muslim majority population is an event in the Luma area with a $100 \%$ Muslim population. After the League of Prizeren (June 18897), in the framework of 
the national movement AvdylFrashëri, one of the main founders of the League, comes to the Luma area to inspire the national movement against Turkey. He knocked on the doors as a guest in the village of Palush in the province of Bushtricë. All the time he tries to convince the assembly and those present by telling them that the Albanians, in order to escape from this great danger that is coming, must rise up against Father Sultan, but it was impossible to convince them. When he did not succeed in this way, after thinking over the night, the other day, in the morning he told about his dream: "During the night, while sleeping, Hazrat Muhammad appeared to me in a dream and said to me: evils and dangers."

Only in this way he convinced them. They patriotically rejected it, and religiously accepted it. Despite the interpretations but abundant evidence proves that the Turkish Empire through Islamism had deeply Ottomanized our national feeling.

\section{Conclusions}

The League of Prizren and the Assembly of Vlora were meetings of elites who with their vision aimed to orient their country politically towards the West, but in fact, these ruling elites did not have popular legitimacy. They had all held high positions in the service of the Empire and "escaped" at a time when the Turkish Empire was falling in the Balkans. And further, they sat at the head of these Albanian political mejlis with the prestige they enjoyed from the resources of imperial power, essentially theocratic. A good part of them were former statesmen of the sultan, ulema, myfti, myderriz etc. And this was a reason that the Assembly of Prizren did not refuse the Ottoman as a culture, nor the Shariaas a legal code, not even the Islam as a civilization. Thus, that assembly does not promise to produce a secular state, nor does it denounce the model of sultanate power, although many of the majority delegates refused to violate the borders of the Empire in the Balkans, and the power of sultan. Many of them alluded to a Western model nation, but could not say that they were not legitimized that way. They may have had the content of the nation-state as an illusion, but this illusion remained on the margins of idealism, without becoming a matter for debate in the political assembly. Thus, we, by consuming a lot of nationalist rhetoric in the definition of these two national assemblies, the League of Prizren and Independence, have compromised important elements of the content of these events.

These two assemblies, despite their national aspirations, were mainly produced by theSublime Porte and themajles ofbeysand pashas, the ulema and muftis, so they did not have the illuminist power to distance themselves politically and culturally from all that legacy of the Ottoman Empire. There was nothing wrong with them taking on this mission, because there was no way it could have looked any different, but in terms of the content of their culture, they were not national. But even our society atthe time, had not risen to the level of embracing national ideology. Why? Apart from the past that had to do with the Ottoman, it lacked the social component, because during the National Renaissance, no social transformation of our society took place, and consequently we did not move from rural society to an urban society. There was no 
industrial revolution to bring about any technological innovation, and above all it is not that Albanians rose politically to overthrow political dynasties, to approve any other political system, but on the contrary, they saw the weakening of the Ottoman Empire in the Balkans as a threat to great for Albanians. Therefore, among Albanians, the ethnic enlightenment did not naturally manifest as a national ideology, as history holds, but we became ethnically connected when Russia became stronger and sought expansion in the Turkish Balkans. These geo-political "sparks" are not part of my research, but I want to highlight that the elites of the Albanian political assemblies were fundamentally different from the clubs of poets and writers of the National Renaissance. The Poets' Club cursed the Asian, the Turkish empire, as the cause of evil, while the elite of political assemblies feared the weakening of the Turkish empire in the Balkans, and theyconsidered the storms coming from Russia and the West as a misfortune for the Albanians. It is important in these two different perspectives on the events of the time that the new geopolitics in the Balkans guided and oriented geoculture for Albanians. The poet, prepared the cultural yeast of our identity. Turkish for our renaissance, was the enemy, the ugly, the barbaric, the evil, and they wore all the bad features, so it was the other, different from -out own - Albania. This emerging identity, unlike the Turkish one, was a "poetic contemplation" that would later be used for public consumption in the political discourse after the declaration of independence. The political expulsion of the Turkish Empire from the Balkans and the domination by the Western powers would attempt the cultural distance of the Albanians from the political emperor. Therefore, the cultural product of our national identity began to take on the nuances of Western civilization. Everything oriental would to be rejected by us as it no longer served our political future. The political discourse would reveal long-standing connections to the roots of Western civilization.

\section{Bibliography}

[1] A.Harapi. "From where we start and from where we will be caught" pg.463

[2] AQSH I RPSSH pg. 245 / III.d.6. Pg.123 (Ottoman original)

[3] AQSH I RPSSH, Pg. 245 / III.d.6. Pg.144 (Ottoman original)

[4] AQSH I RPSSH, Pg.245 / III.d.6. Pg.123 (Ottoman original)

[5] AQSH of RPSSH, f. 245 / III.d.6.f.144 (original: Ottoman)

[6] AQSH of RPSSH, f. 245 / III.d.6.f.123 (Ottoman original),

[7] GazmendShpuza (1986). The peasant uprising of Central Albania 1914-1915. RPS Academy of Sciences of Albania, Institute of History

[8] Lulzim Hoxha (October 2013). "The Making of Political Rituals in Albanian Society". Academic Journal of Inter-disciplinary Studies MCSER Publishing, Rome-Italy. 2 (8): 18

[9] LulzimHoxha (October 2013). "The Making of Political Rituals in Albanian Society". Academic Journal of Interdisciplinary Studies MCSER Publishing, Rome-Italy. 2 (8): 18 
[10] Memorandum of Ismail Qemali. February 12, 1312; February 24, 1897.f. 14. Summary of documents published on the occasion of the 70th anniversary of the Declaration of Independence. Publishing house; November 8th.

[11] O. Schmitt. Albanians a story between East and West, Guttenberg, Tirana 2012. Pg.16

[12] Publication of the state archive (originally Ottoman) Text of the Declaration of Independence of Albania, November 28, 1912.

[13] Robert Elsie (2013). A Biographical Dictionary of Albanian History. I.B.Tauris. pg. 376.

[14] Robert Elsie (2013). A Biographical DictionaryofAlbanian History. I.B.Tauris. p. 376. Gazmend Shpuza (1986). The peasant uprising of Central Albania 1914-1915. RPS Academy of Sciences of Albania, Institute of History

[15] Summary of documents 1888-1919 publishing house 8 November. Published on the occasion of the $70^{\text {th }}$ anniversary of the declaration of independence.

[16] Summary of documents 1888-1919 publishing house 8 November. Published on the occasion of the $70^{\text {th }}$ anniversary of the declaration of independence

[17] Summary of documents 1888-1919 publishing house 8 November. Published on the occasion of the $70^{\text {th }}$ anniversary of the declaration of independence

[18] The text of the declaration of the Declaration of Independence of Albania, November 28, 1912. 